The nighthawk is not only a bird of dusk to dawn; sometimes, even at midday, it will fly off its roost, swooping suddenly down like a dropped stone, while the rush of air through the stiff flight feathers produces a sound like a snapped bow string. They catch themselves with a jerk and spiral away on high again to repeat their performance, over and over and over. It is a sound that gives me the greatest joy. It is believed to be a mating display, but I have heard it continued long into the summer - probably as a territoryclaiming performance. I like to think it is from the sheer ecstasy of life. For it is written: "The beasts of the field shall honour me... the dragon and the owls."

Another habit of nighthawks that has given me countless hours of pleasure is when I remain out late into our short summer nights to hear their rather nasal call - a peent or pee-ik or pee-it - a penetrating cry, softened by distance and regularly repeated. This call may be heard all night, even until full day, when the hot sun sends them to rest.

I love these slender, slim-winged birds with their ugly, rounded heads and great eyes and whiskery, cavernous mouths. They are a delight to me.

\title{
HOODED WARBLER IN REGINA
}

FRANK H. BRAZIER, 2657 Cameron St., Regina, Saskatchewan. S4T 2W5

Sunday 26 May 1985 was a fine spring day in Regina with the sun shining brightly. About noon I received a telephone call from Bob Luterbach advising me that he, Chris Adams and Robert Kreba had a female Hooded Warbler under observation in Regina Cemetary. I drove there immediately, joined the others and soon found the bird hunting food in a tree. We had excellent views, noting the field marks so there was no doubt as to the identity. It was a "lifer" for me.

I do not know who discovered the bird. The only account I have seen was a report which appeared in American Birds, Vol. 30, p. 316, issue of Fall 1985. Relatively few members of the Saskatchewan Natural History Society ever see American Birds, so, as one of the observers, I am reporting the occurrence of this rare visitor, Saskatchewan's first, for their benefit. Other observers came after I left as the warbler remained in the vicinity for some time. By virtue of a number of recognizable photographs this Hooded Warbler is now on the confirmed list of Saskatchewan birds. 